\title{
The Explanatory Variables of Outward Foreign Direct Investment: Panel Evidence
}

\author{
${ }^{1}$ Nicholas Apergis, ${ }^{2}$ Dimitrios Asteriou and ${ }^{2}$ Kalliroi Papathoma \\ ${ }^{1}$ Department of Banking and Financial Management, \\ University of Piraeus, 80 Karaoli and Dimitriou, 18534 Piraeus, Greece \\ ${ }^{2}$ Hellenic Open University, Greece
}

\begin{abstract}
Along with the traditional macroeconomic determinants of FDI, additional explanatory variables, such as the exchange rates, should be encountered in undertaking physical investment decisions, as these variables affect several comparative costs and the cost of lending. The goal of this study is to examine for the first time panel data evidence of Greek outward FDI flows directed to $16 \mathrm{EU}$ and non-EU countries over the period 1997-2008, focusing on the relative importance of emerging variables on the determination of the direction of FDI. The results clearly show that-under different specifications-increases in the level of exchange, affect FDI flows directed from Greece to the host economies. Moreover, significant determinants for the streaming of the Greek FDI are the minimum wage rate and the labour productivity in the host economies as well as the price of the Greek physical capital.
\end{abstract}

Keywords: Foreign Direct Investment, Exchange Rate, Wage Rate, Labour Productivity

\section{INTRODUCTION}

It is well sustained in several studies (Froot and Stein, 1991; Goldberg and Klein, 1997; Barrell and Pain, 1998; Sazanami et al., 2003) that exchange rates, although not considered to be among the traditional macroeconomic determinants of Foreign Direct Investment (FDI), it can actually affect the composition and the direction of real capital flows. Many analysts use exchange rates to measure the competitiveness of an economy in terms of the purchasing power of its currency. Thus, exchange rate alterations may change the competitiveness of an economy and, finally, shift FDI the absorptions of FDI flows to this region. In general, exchange rates are expected to act as a determinant of portfolio financing, but they can also determine several types of comparative costs of the undertaken real capital investments, such as FDI. Lipsey (1999) argues that although FDI is considered to be a more stable form of investment than portfolio investment, certain variables, i.e., exchange rate, that actually determine the volume short-term capital flows and portfolio financing, can also affect the composition and the direction of real capital flows.

The relevant importance of exchange rates in the determination of long-term capital flows may be stronger than that in the determination of portfolio financing, as portfolio investors can hedge against financial risks of exchange rate fluctuations by diversifying through the derivative markets. By contrast, foreign direct investors undertaking long-term investments, they are not very flexible in diversifying risks and they should consider not only traditional macroeconomic determinants, such as relative labor costs but also the level of exchange rates, which affects several types of comparative costs. In particular exchange rates give rise to transaction risks and risks related in with financial crises, while they are also associated with transaction costs, which affect investment costs as well as the cost of lending. Hence, exchange rates are integrally linked with the behavior of the Multinational Corporations (MNCs), which are considered to be the major carrier for the steaming of FDI worldwide.

Corresponding Author: Nicholas Apergis, Department of Banking and Financial Management, University of Piraeus, 80 Karaoli and Dimitriou, 18534 Piraeus, Greece 
Moreover, exchange rates can also affect the financial value and the profits of the MNCs. In this framework, exchange rates can act as a major determinant for the undertaken FDI.

Since in some cases exchange rates may affect the composition of physical capital investments even more than they would affect financial investment decisions, we consider the importance of analyzing the role of this variable for the determination of the volume and the allocation of FDI. This study focuses on the relative importance of the level of exchange rates for the determination of the Greek outward FDI flows directed to $16 \mathrm{EU}$ and non-EU countries over the period 19972008. Since the previous literature findings are ambiguous and most of the studies so far do not provide theoretical contribution on the topic, our panel data analysis is sustained on a theoretical model in order to contribute with new evidence on the topic. The study is organized as follows. The next section reviews the literature on the association between FDI and exchange rates, while the following section presents the theoretical background behind the testable hypothesis. The next section presents the empirical analysis and discusses the empirical findings, while the final section concludes the study.

\subsection{The Literature on FDI and Exchange Rates}

The FDI literature examines the relevant influence of exchange rates on the allocation of real capital flows by severing it into the impact of: (a) the level of exchange rates and (b) exchange rate volatility. Alterations of FDI flows, due to changes in exchange rates, are reflected both in outflows from the home countries and in inflows to host countries. In general, the literature on FDI and on exchange rates documents that a weaker currency in the host countries leads to robust increases in FDI inflows to the depreciated economies (Froot and Stein, 1991; Goldberg and Klein, 1997; Barrell and Pain, 1998) and that a stronger currency in the home economy enhances FDI from the home to the host economies (Klein and Rosengren, 1994; Blonigen, 1997; Sazanami et al., 2003). In particular, potential depreciations in the host country's currency are expected to generate positive effects on inward FDI to the host countries, because the depreciation improves the international competitiveness of the host economy and, thus, the profitability of FDI. In particular, the facilities in the host country become less expensive for the foreign investors, the value of foreign financial flows increases and, finally, more FDI is attracted to the depreciated region.

In contrast, negative effects can be also attributed due to the lower expected profit repatriations to the home economy, if profits are nominated in the host country's currency. Moreover, in the long run, depreciations in the host country's currency may cause inflation and, finally, reduce its international competitiveness. Negative effects could be also be attributed for the MNCs to the long-run depreciation in the host economy may reduce the value of the subsidiaries located in the host country and may eventually reduce the total value of the parent $\mathrm{MNC}$ (Apergis et al. (2000) for a detailed explanation). Apergis et al. (2000) and De Menil (1997) suggest that the negative effects dominate and, thus, exchange rate depreciations in the host country lead to lower inward FDI.

Considering the outflows from the home countries, potential appreciations in the home country's currency are expected to generate positive effects on outward FDI flows from the home to host economies. That is because the appreciation of the home currency increases the production cost in the home economy, which it term becomes less competitive. Consequently, FDI allocation is shifted from the home to lower cost economies.

The literature findings on the relation between FDI and exchange rate volatility also reports ambiguous results. Cushman (1985; 1988); Goldberg and Kolstag (1995); De Menil (1997) and Pain and Welsum (2003) argue that exchange rate volatility is associated with higher FDI activity, because foreign investors relocate production activities to avoid transaction risks or to take advantage of price differences to lower cost economies. In contrast, Goldberg (1993); Campa and Golberg (1995); Benassy-Ouere et al. (2001); Urata and Kawai (2000); Kiyota and Urata (2004) and Brzozowski (2006) argue that exchange rate volatility reduces FDI flows due to the transaction risks and the consequent reduced investments activity.

\subsection{Theoretical Background}

Most of the studies that analyze the relationship between FDI and exchange rates are based only on empirical grounds, using ad hoc mythologies. In this study the empirical investigation is based on a theoretical model which adopt examines theoretically basic determinants of outward FDI, focusing on the role of the level of the exchange rate of the home per host country's currency, along with the nominal wage rate and the labour productivity in the host economy and the price of physical capital in the home economy. The equilibrium theoretical model considers the location choice of a MNC which produces a good, using two inputs: (a) Physical Capital (K) and (b) Labour (L). The model is incorporated in a two country world, where countries are characterized as the Home Country (Country 1) and the Host Country (Country 2). To the best of our knowledge this study is the first to introduce endogenously the role 
of the MNCs in a model that links the possible impact of the exchange rate with the undertaken FDI, under principal assumptions of the Theory of the MNCs. The representative $\mathrm{MNC}$ is a Horizontal MNC which locates headquarters in the Home Country (Country 1) and production activities both in Home Country (Country 1) and in the Host Country (Country 2). It is also assumed that good production and final product are identical in both countries. The primary aim of the Horizontal MNC is to avoid any kind of transportation costs and tariffs, as the good is produced and consumed locally in each of the two economies. The final good is not exported back in the home market, as in each country the production of the good serves the demand of the local plant For a more detailed analysis see Markusen and Maskus (1999); Markusen (2002) and Carr et al. (2001). Thus individuals may either buy the good in the investing country or in the host country, as the good is not being intra-firm traded or exported between the two economies. In order for the MNC to dominate production in the host economy, it has to benefit from the comparative advantage (The Theory of the Comparative Advantage, Hymer (1976). While compared with local firms in the host economy the MNC has better know-how, managerial and financial expertise, but on the other hand local firms have better knowledge of the market in which they operate. Thus in order for the MNC to remain competitive it has to hold a low cost specific advantage. It is assumed that the nominal wages in the recipient economy (Country 2) are lower than in the mother economy (Country 1) and that this cost deferential reduces the cost of labour in the host economy and acts as the primary motive for the MNC to undertake FDI in the host country. Finally it is also assumed that the skilled labour force in the Home country (Country 1) is more abundant than in Host Country (Country 2), so if the MNC decides to undertake FDI it will face an additional training cost of labour in the Host economy. Finally it is assumed that before initial production takes place, the MNC uses physical capital (K) purchased in the home market in domestic prices $\left(\mathrm{P}_{\mathrm{k}}\right)$. The $\mathrm{MNC}$ faces a profit maximization problem, considering whether it is prosper to locate production both in the domestic market and abroad and this decision is based on constraints such as the cost of capital, the cost of labour, fixed costs and the level of the exchange rate.

The theoretical predictions of the model are summarized in Equation 1 and 2, which interpret final results for Country 1 and Country 2 respectively:

$$
\frac{\partial \mathrm{f}_{1}\left(\mathrm{~L}_{1}, \mathrm{~K}_{1}\right)}{\partial \mathrm{K}_{1}}=\frac{\mathrm{P}_{\mathrm{k}}}{\mathrm{W}_{1}} \frac{\partial \mathrm{f}_{1}\left(\mathrm{~L}_{1}, \mathrm{~K}_{1}\right)}{\partial \mathrm{L}_{1}}
$$

where, $\left(\frac{\partial \mathrm{f}_{1}\left(\mathrm{~L}_{1}, \mathrm{~K}_{1}\right)}{\partial \mathrm{K}_{1}}\right)$ represents the marginal capital productivity in Country $1,\left(\mathrm{P}_{\mathrm{k}}\right)$ denotes the price of physical capital in Country $1,\left(\mathrm{~W}_{1}\right)$ denotes the nominal wage rate in the Country 1 and $\left(\frac{\partial \mathrm{f}_{1}\left(\mathrm{~L}_{1}, \mathrm{~K}_{1}\right)}{\partial \mathrm{L}_{1}}\right)$ denotes the marginal labour productivity in Country 1 :

$\frac{\partial \mathrm{f}_{2}\left(\mathrm{~L}_{2}, \mathrm{~K}_{2}\right)}{\partial \mathrm{K}_{2}}=2 \mathrm{P}_{\mathrm{k}} \frac{\mathrm{E}}{\mathrm{W}_{2}} \frac{\partial \mathrm{f}_{2}\left(\mathrm{~L}_{2}, \mathrm{~K}_{2}\right)}{\partial \mathrm{L}_{2}}$

where, $\left(\frac{\partial \mathrm{f}_{2}\left(\mathrm{~L}_{2}, \mathrm{~K}_{2}\right)}{\partial \mathrm{K}_{2}}\right)$ represents the marginal capital productivity in Country 2, (E) denotes the exchange rate between Country's 1 currency per Country's 2 currency, $\left(\mathrm{W}_{2}\right)$ denotes the level of the nominal wage in Country 2 and $\left(\frac{\partial \mathrm{f}_{2}\left(\mathrm{~L}_{2}, \mathrm{~K}_{2}\right)}{\partial \mathrm{L}_{2}}\right)$ denotes the marginal labour productivity in Country 2.

Equation 1 represents results for the Home Country (Country 1) end indicates that potential increases in the price of capital $\left(\mathrm{P}_{\mathrm{k}}\right)$ or increases in the marginal labour productivity in Country $1\left(\frac{\partial \mathrm{f}_{1}\left(\mathrm{~L}_{1}, \mathrm{~K}_{1}\right)}{\partial \mathrm{L}_{1}}\right)$, are associated with increases in the marginal capital productivity in Country $1\left(\frac{\partial \mathrm{f}_{1}\left(\mathrm{~L}_{1}, \mathrm{~K}_{1}\right)}{\partial \mathrm{K}_{1}}\right)$. Equation, 1 also shows that potential increases in the nominal wage rate in the Country $1\left(\mathrm{~W}_{1}\right)$, cause decreases in the marginal capital productivity in Country $1\left(\frac{\partial \mathrm{f}_{1}\left(\mathrm{~L}_{1}, \mathrm{~K}_{1}\right)}{\partial \mathrm{K}_{1}}\right)$.

Equation (2) shows results for the Host economy which actually absorbs FDI and thus becomes the focus of our analysis. Equation (2) interprets the marginal capital productivity in Country $2\left(\frac{\partial \mathrm{f}_{2}\left(\mathrm{~L}_{2}, \mathrm{~K}_{2}\right)}{\partial \mathrm{K}_{2}}\right)$ and signals for the expected efficiency of the undertaken FDI in the host economy. It is observed that there exists a positive relationship between the price of capital in the home economy $\left(\mathrm{P}_{\mathrm{k}}\right)$ and the marginal capital productivity in Country $2\left(\frac{\partial \mathrm{f}_{2}\left(\mathrm{~L}_{2}, \mathrm{~K}_{2}\right)}{\partial \mathrm{K}_{2}}\right)$. Moreover, Equation 2 indicates that the expected efficiency of the undertaken FDI by the MNC in Country $2\left(\frac{\partial \mathrm{f}_{2}\left(\mathrm{~L}_{2}, \mathrm{~K}_{2}\right)}{\partial \mathrm{K}_{2}}\right)$ is 
positively correlated with the exchange rate between Country's 1 currency per Country's 2 currency (E). Thus, potential increases of the exchange rate reflect either appreciations of the Home Country's currency or deprecations of the Host country's currency. In the first case, the appreciation of the Home Country's currency would increase the production cost in the mother economy, inducing the Home Country to become less competitive. In the second case, the depreciation of the Host Country's currency would reduce the production cost in the host economy and would finally increase its international competitiveness. In both cases, when other things being equal, increases in the level of exchange rate would enhance FDI activity from the home to the host economy, supporting what has been suggested by several studies in this scientific area (Froot and Stein, 1991; Ito et al., 1996; Goldberg and Klein, 1997; Barrell and Pain, 1998; Cushman, 1988; Urata and Kawai, 2000; Benassy-Ouere et al., 2001; UN, 2008). A positive relationship is also observed between the marginal productivity of labour in Country 2 $\left(\frac{\partial \mathrm{f}_{2}\left(\mathrm{~L}_{2}, \mathrm{~K}_{2}\right)}{\partial \mathrm{L}_{2}}\right)$ and the expected efficiency of the undertaken FDI $\left(\frac{\partial \mathrm{f}_{2}\left(\mathrm{~L}_{2}, \mathrm{~K}_{2}\right)}{\partial \mathrm{K}_{2}}\right)$. It was initially assumed, the physical capital used in the production process in both countries has been acquired by the MNC in the Home Country, which is more developed than the Host economy. The Home economy market is supposed to be well organized and factors of production to be very productive up to the offer of final products. So, potential increases in the prices of the productive factors could be related with the establishment of higher specifications in the process of their improvement. Thus potential increases in their prices could be also related with improvements of their output and efficiency improvements of the undertaken investment in both countries. When other things being equal and labor productivity in Country 2 increases, production in Country 2 becomes more competitive, attracting more FDI from the Home to the Host economy note that this assumption only holds if the increase in productivity is not accompanied by similar increase in nominal wages or prices, which affect the level of exchange rate. This effect of labor productivity in the host economy on the undertaken FDI from the home economy could be stronger if FDI is intended for labor transfer in the host economy. In such a case the larger the labor productivity increases in the Host economy, the greater will be the FDI outflows from the home to the cost economy.
Finally, Equation 1 and 2 interprets a negative relationship between the level of the nominal wage in Country $2\left(\mathrm{~W}_{2}\right)$ and the marginal capital productivity in Country $2\left(\frac{\partial \mathrm{f}_{2}\left(\mathrm{~L}_{2}, \mathrm{~K}_{2}\right)}{\partial \mathrm{K}_{2}}\right)$, implying that potential increases in the prices of nominal wages in the Host economy, would increase the production cost for the $\mathrm{MNC}$ and would finally lead to the reduction of the undertaken FDI in the Host Country, an evidence that is also supported by Baek and Okawa (2001) and Klein and Rosengren (1994).

The term $\left(\frac{\partial \mathrm{f}_{2}\left(\mathrm{~L}_{2}, \mathrm{~K}_{2}\right)}{\partial \mathrm{K}_{2}}\right)$ in Equation 2 represents in the marginal capital productivity in the Host Country and signals for the expected efficiency of the outward FDI in the host economy. Equation, 2 could be also written as:

$\mathrm{FDI}_{2}=2 \mathrm{P}_{\mathrm{k}} \frac{\mathrm{E}}{\mathrm{W}_{2}} \mathrm{LGDP}_{2}$

where, $\mathrm{FDI}_{2}=\frac{\partial \mathrm{f}_{2}\left(\mathrm{~L}_{2}, \mathrm{~K}_{2}\right)}{\partial \mathrm{K}_{2}}$ could be denoted by the outward FDI stock or the net outward FDI flows or the change in outward FDI flows from the Home to the Host economy. $\mathrm{LGDP}_{2}=\frac{\partial \mathrm{f}_{2}\left(\mathrm{~L}_{2}, \mathrm{~K}_{2}\right)}{\partial \mathrm{L}_{2}}$ expresses the marginal inverse labour productivity ratio in the host economy. Then, a log-linearization of Equation 3-5 is obtained as:

$\log \mathrm{FDI}_{2}=\log \left(2 \mathrm{P}_{\mathrm{k}} \frac{\mathrm{E}}{\mathrm{W}_{2}} \mathrm{LGDP}_{2}\right)$

And:

$\log \mathrm{FDI}_{2}=2 \log \mathrm{P}_{\mathrm{k}}+\log \mathrm{E}-\log \mathrm{W}_{2}+\log \mathrm{LGDP}_{2}$

Henceforth, lower-case letters denote the logarithm of a variable; $\mathrm{x} \equiv \log \mathrm{X}$ :

$\mathrm{fdi}_{2}=\mathrm{a}_{1} 2 \mathrm{p}_{\mathrm{k}}+\mathrm{a}_{2} \mathrm{e}-\mathrm{a}_{3} \mathrm{w}_{2}+\mathrm{a}_{4} \lg \mathrm{dp}_{2}$

Equation, 6 could be also expressed into a linear panel data model of the form Equation (7):

$\mathrm{y}_{\mathrm{it}}=\mathrm{a}_{\mathrm{i}}+\mathrm{x}_{\mathrm{it}} \beta+\mathrm{u}_{\mathrm{it}}$ 
where, the pair of terms $(i, t)$ express the transversal and temporal aspects of the per country panel data, $y$ and $x$ are respectively the dependent variable and the matrix of explanatory variables and $\mathrm{a}_{\mathrm{i}}$ is a parameter specific to each country. The latter parameter (which varies only across countries and not over time) is introduced to take account of unmeasured features specific to the countries concerned. In order to assess the influence of the variables described, the outward FDI Equation 6 may be built up in the following linear form:

$$
\begin{aligned}
& \left(\mathrm{fdi}_{2}\right)_{\mathrm{i}, \mathrm{t}}=\mu_{\mathrm{i}}+\mathrm{a}_{1} 2\left(\mathrm{p}_{\mathrm{k}}\right)_{\mathrm{i}, \mathrm{t}}+\mathrm{a}_{2}(\mathrm{e})_{\mathrm{i}, \mathrm{t}} \\
& -\mathrm{a}_{3}\left(\mathrm{w}_{2}\right)_{\mathrm{i}, \mathrm{t}}+\mathrm{a}_{4}\left(\operatorname{lgdp_{2}}\right)_{\mathrm{i}, \mathrm{t}}+\varepsilon_{\mathrm{i}, \mathrm{t}}
\end{aligned}
$$

\section{MATERIALS AND METHODS}

\subsection{Data and Methodology}

The econometric estimation considers the impact on Greek outward FDI, when FDI is directed to 16 host countries (Belgium, France, Germany, Ireland, Italy, Luxemburg, Netherlands, Portugal, Spain, Denmark, UK, Albania, Bulgaria, Romania, Cyprus, U.S.A.) spanning the period 1997-2008. Due to firm level-data unavailability, estimation of Equation 8 applied using country aggregate data. The data set used in this study is compiled by 5 different sources: Bank of Greece, Eurostat (2009), IMF-WEO (2009), Wordbank indicators "2008" and Penn World Tables 6.3. The methodology used is panel data. We estimate Equation 8 under three different methods (namely common constant, fixed effects and random effects), in order to test our data sample under different specific-country characteristics estimations.

In particular, we estimate the impact of the macroeconomic determinants described in Equation 8 on Greek outward FDI directed to 16 host countries. As dependent variable is the logarithm of Greek outward FDI stock directed to the 16 host countries, $\left(\mathrm{fdi}_{2}\right)_{\mathrm{i}, \mathrm{t}}$. This variable signals for the efficiency of Greek outward FDI. As independent variables in Equation 8 are defined, the logarithm of the price of physical capital in Greece $\left(p_{k}\right)_{i, t}$, expressed in our estimations using the Producer Price Index (PPI) for the domestic prices of industry capital in Greece, the logarithm of the exchange rate of the home country currency per host country's currency $(e)_{i, t}$, defined as the annual average exchange rate of Ecu/Euro per each of the national currencies of the 16 host countries. The motive of the Horizontal multinational form to invest in low cost economies is captured by the logarithm of the minimum level of nominal wage in each of the 16 host countries $\left(\mathrm{w}_{2}\right)_{\mathrm{i}, \mathrm{t}}$. We expect a negative influence of this variable. Coefficient $\left(\operatorname{lgd} p_{2}\right)_{i, t}$ is introduced as an index that measures the marginal labor productivity in each of the 16 host countries. This variable is defined as the logarithm of the ratio of total employment over annual real GDP in each of the 16 host countries and signals for the marginal productivity of the undertaken FDI and for the absorbing capacity of labor intensive investments. In order to extensively analyze the possible impacts on Greek outward FDI, we test 3 samples by distinguishing potential effects of the macroeconomic determinants described above on FDI that is directed to: (a) all the 16 host countries, (b) the 9 Eurozone countries and (c) the 7 non Eurozone coutries.

\section{RESULTS AND DISCUSSION}

\subsection{Empirical results}

Table 1-3 present the results for the impacts on the Greek outward FDI, when this is directed to 16 host countries, to 9 Eurozone countries and to 7 non Eurozone countries, respectively. In the first column of each table the independent variables included in the regressions are defined. The second, the third and the fourth column of each table present the results under the assumption that there are no differences between the economies (common constant), under the measurement of specific country features (fixed effects) and under the consideration of random country characteristics (random effects), respectively.

Table 1. Greek outward FDI directed to 16 countries

\begin{tabular}{llll}
\hline Variable & Common constant & Fixed effects & Random effects \\
\hline C & $-7730090(-0,874672)$ & & $2177230(0,280340)$ \\
The exchange rate & $-0,357057(-3,356137)^{*}$ & $0,251230(0,576179)$ & $-0,179956(-0,650987)$ \\
Marginal labor productivity in the host countries & $-0,919312(-1,676578)^{* *}$ & $-0,591358(-0,414417)$ & $0,409201(0,567260)$ \\
Price of Greek physical capital & $5,961,693(3,438557)^{*}$ & $4,273,765(4,414558)^{*}$ & $4,542,370(4,894058)^{*}$ \\
Minimum nominal wage rate in the host countries & $-1,623,440(-2,714466)^{*}$ & $0,059859(0,103690)$ & $-0,002320(-0,004211)$ \\
R- squared & 0,289204 & 0,873257 & 0,264297 \\
Observations & 104 & 104 & 104 \\
\hline
\end{tabular}

t-statistics in the parenthesis, *, **; Denote statistical significance at 5 and $10 \%$, respectively 
Table 2. Greek outward FDI directed to 9 Eurozone countries

\begin{tabular}{llll}
\hline Variable & Common constant & Fixed effects & Random effects \\
\hline C & $-3,412,621(-3,216800)^{*}$ & & $-1,238,110(-0,781287)$ \\
The exchange rate & $0,421569(2,440232)^{*}$ & $0,274368(0,631917)$ & $0,264338(0,744965)$ \\
Marginal labor productivity in the host countries & $-2,527,094(-3,570733)^{*}$ & $9,219,487(2,363922)^{*}$ & $0,066565(0,039798)$ \\
Price of Greek physical capital & $6,286,112(3,004405)^{*}$ & $6,534,571(3,147567)^{*}$ & $4,486,299(2,745800)^{*}$ \\
Minimum nominal wage rate in the host countries & $-1,003,561(-0,882957)$ & $1,081,473$ & $1,304,608(0,671832)$ \\
R- squared & 0,313945 & 0,872223 & 0,140507 \\
Observations & 67 & 67 & 67 \\
\hline
\end{tabular}

t-statistics in the parenthesis, $* * *$ denote statistical significance at 5 and $10 \%$, respectively

Table 3. Greek outward FDI directed to 7 non- Eurozone countries

\begin{tabular}{|c|c|c|c|c|c|}
\hline Variable & $\begin{array}{l}\text { Common } \\
\text { constant }\end{array}$ & $\begin{array}{l}\text { Fixed } \\
\text { effects }\end{array}$ & $\begin{array}{l}\text { Common } \\
\text { constant }\end{array}$ & $\begin{array}{l}\text { Fixed } \\
\text { effects }\end{array}$ & $\begin{array}{l}\text { Random } \\
\text { effects }\end{array}$ \\
\hline$\overline{\mathrm{C}}$ & $\begin{array}{l}7,926,827 \\
(-1,149,757)\end{array}$ & & $\begin{array}{l}1,362,874 \\
(2,173100)^{*}\end{array}$ & & $\begin{array}{l}1,614,639 \\
(2,840231)^{*}\end{array}$ \\
\hline The Exchange Rate & $\begin{array}{l}1,893,013 \\
(3,142648)^{*}\end{array}$ & $\begin{array}{l}9,549,641 \\
(3,150681)^{*}\end{array}$ & $\begin{array}{l}-1,783,908 \\
(-8,824903)^{*}\end{array}$ & $\begin{array}{l}4,326,265 \\
(2,381100)^{*}\end{array}$ & $\begin{array}{l}-1,524,260 \\
(-3,699138)^{*}\end{array}$ \\
\hline Marginal labor productivity in the host countries & $\begin{array}{l}-0,732773 \\
(-1,560094)\end{array}$ & $\begin{array}{l}-1211019 \\
(-3,162325)^{*}\end{array}$ & $\begin{array}{l}0,894458 \\
(6,066370)^{*}\end{array}$ & $\begin{array}{l}-5834372 \\
(-2,449836) *\end{array}$ & $\begin{array}{l}0,847411 \\
(2,681011)^{*}\end{array}$ \\
\hline Price of Greek physical capital & $\begin{array}{l}1,152,617 \\
(0,827692)\end{array}$ & $\begin{array}{l}-1,483,572 \\
(-0,884176)\end{array}$ & $\begin{array}{l}3,509,774 \\
(2,688667) *\end{array}$ & $\begin{array}{l}-0,505267 \\
(-0,351439)\end{array}$ & $\begin{array}{l}2,817,531 \\
(2,685007)^{*}\end{array}$ \\
\hline Minimum nominal wage rate in the host countries & $\begin{array}{l}-0,155905 \\
(-0,405508)\end{array}$ & $\begin{array}{l}-2,017,305 \\
(-2,117168)^{*}\end{array}$ & -- & -- & -- \\
\hline R-squared & 0,367047 & 0,538350 & 0,638625 & 0,799159 & 0,217046 \\
\hline Observations & 37 & 37 & 60 & 60 & 60 \\
\hline
\end{tabular}

t-statistics in the parenthesis, *,**; Denote statistical significance at 5 and $10 \%$, respectively

When the Greek outward FDI is absorbed from all the 16 host countries, the results in Table 1 show that all the independent variables enter with statistical significance under the assumption that there are no differences among the 16 economies (second column). In particular, the level of exchange rate is reported to have a negative impact on FDI, implying that increases of the exchange rate of Euro per host countries currency cause decreases on the Greek outward FDI. This result is in line with what suggested by several studies (Apergis et al., 2000; De Menil, 1997; Campa, 1993), arguing that potential depreciations of the host countries currency may finally lead to lower outward FDI to the depreciated economies. A negative and statistical relationship is also observed between the level of minimum nominal wage, the marginal labor productivity and the outsource of Greek outward FDI, under the assumption that there are no differences among the 16 economies (second column). Our results suggest that increases in the nominal wages of the host economies are associated with lower Greek outward FDI to the higher cost economies, confirming theoretical predictions as well as the findings by Baek and Okawa (2001) and Klein and Rosengren (1994). An important finding for the streaming of the Greek outward FDI is also the statistical significance of marginal labor productivity in the host economies. The negative sign of this variable is not unpleasant on the aggregate level, since the sign of the impact for labor productivity is determined by the sectors in which the firms operate, by what the firms intent to carry and by labor productivity deferential across economies under study. One would expect increases in labor productivity in the host countries to be related with the absorption of more FDI by the more competitive economies. However, if the MNC intends to carry technology or managerial skills to the host regions and use the competitive advantage of these elements over its competitors, then the larger the productivity differential between the home and the host country, the greater the FDI flows to the host economy are. Baek and Okawa (2001) support that labor productivity deferential between the home and the host country, determine FDI flows to the host economy. Finally, the results in Table 1 show that under all the tree estimation methods, the price of the Greek physical capital causes a positive and significant effect on the Greek outward FDI directed to the 16 host countries. This result is in line with theoretical predictions and the argument that Greek investors prefer the adoption of Greek physical capital for foreign investments. It seems that the high growth rates that Greece witnessed over the estimated period reflect a long-run infrastructure development at all production stages. In this framework, 
potential increases in the prices of the productive factors are related with the establishment of higher specifications in the process of their improvement. Thus, potential increases in their prices could be also related with improvements of their output and efficiency improvements of the undertaken investment in both countries, supporting the preference of Greek foreign investors to use Greek physical capital to their ventures.

Table 2 presents results for the impact on Greek outward FDI, when this is directed to 9 Eurozone countries. Estimations are important for the role of horizontal MNCs on the undertaken investments, since this type of FDI is mainly directed among developed economies. Results interpret the catalytic role played by exchange rates even within the Eurozone, supporting that the level of exchange rates is positively correlated with the streaming of the Greek FDI to the EU. Since the sample estimated spans before the adoption of Euro by all the cross section identifiers, the empirical results show that potential appreciations of the Euro or depreciations of the host countries currency are linked with higher Greek outward FDI within the estimation period. This outcome confirms what has been supported by the studies of Froot and Stein (1991); Goldberg and Klein (1997); Barrell and Pain (1998); Klein and Rosengren (1994); Blonigen (1997) and Sazanami et al. (2003). The study displays that even within the Eurozone, the determinants of short-term capital flows and portfolio financing can also affect the composition and the direction of real capital flows. The potential and positive role played by the price of the Greek physical capital also arises when FDI is directed among the EU economies under the three alternative methods of estimation. The impact of marginal labor productivity in the host countries appears significant under the assumption that there are no dereferences among the host economies and under the consideration of specific country characteristics. The direction of this impact on Greek outward FDI has an ambiguous sign at the aggregate level. Finally, nominal wages in the host economies do not play significant role for the outward Greek FDI.

Table 3 presents the results for the impact on the Greek outward FDI when this is directed to 7 nonEurozone countries. Due to data unavailability, the statistical procedure does not provide results for the random effects estimations. Henceforth, the observations concerning nominal wages in the host economies are excluded from the panels, as being the variable with the lower number of observations. Regressions are reestimated and the results are presented in columns 4-6 of
Table 3. The most important finding here is that the statistical significance under all estimations of exchange rates as a determinant of outward FDI. However, the impact of this factor varies depending on the number of observations estimated in the panels and on the alternative estimation methods. The results show that when Greek investors encounter the specific characteristics of the non-Eurozone host economies, exchange rates are positively correlated with FDI. In this case, potential appreciations of the Euro or depreciations of the host countries currencies attract more Greek outward FDI to the non-Eurozone economies. The marginal labor productivity again appears to play a significant role for the Greek outward FDI, having ambiguous influence on the aggregate level. The potential role played by the price of the Greek physical capital turns out to be positive and statistically significant, indicating that the use of Greek physical capital is very important for the increase of the share of Greek FDI outside the Euzonone. Finally, when the nominal wage rate of the host economies is included in the panels as an independent variable, it appears to be negatively correlated with the Greek outward FDI.

\section{CONCLUSION}

This study empirically assesses the potential impacts of the macroeconomic determinants on Greek outward FDI with focus on the relevant influence of the exchange rate of the Euro per host countries currencies. The results clearly show that the exchange rate appears as a strongly significant variable for the streaming of the Greek outward FDI. In particular, the exchange rate was found to be negatively correlated with FDI, when the later was directed to all the 16 host economies examined in this study. This empirical finding suggests that potential depreciations of the host countries currency may lead to lower outward FDI to the depreciated economies. When the Greek outward FDI is directed only to EU economies, we documented a positive association between the exchange rate and the outsourcing of the Greek outward FDI, indicating that appreciations of the Euro or depreciations of the European countries currencies is associated with increases on the Greek outflow to the European economies. When the results are estimated examining the exchange rate of the Euro per non-Eurozone countries currencies, exchange rates appear as a significant factor in determining the Greek outward FDI under all the different methods of estimation. Results show that when Greek investors encounter the specific 
characteristics of the non-Eurozone host economies, the exchange rate was positively associated with FDI. In this case, potential appreciations of the Euro or depreciations of the host countries currencies attract more Greek outward FDI to the non- Eurozone economies.

This study also revealed the catalytic role plaid by the minimum wage rate and marginal labor productivity of the host economies, in attracting the Greek outward FDI. Results show that increases in the nominal wage rate of the host economies discourage the Greek foreign investors from undertaking FDI, suggesting that lowercost labor economies attract more FDI. Nevertheless, a neutral influence of this variable is observed when FDI is directed to Euro-member states. In addition, an important finding that was found was the consistent influence of the marginal labor productivity under alternative methods of estimations. The results show that labor productivity appears as a significant factor for the absorption of FDI flows within and outside the Eurozone economies, having ambiguous directions of its impact on the aggregate level. This outcome suggests that the signs of the impact for labor productivity are determined by the sectors in which the firms operate, by what the firms indent to carry and by labor productivity deferential across the economies. Finally, the study showed that the price of the Greek physical capital caused a positive and significant effect on the Greek outward FDI. This result demonstrates that Greek investors prefer to use Greek physical capital for foreign investments. It seems that the high growth rates that Greece witnessed over the estimated period, reflect a long-run infrastructure development at all production stages, where increases in the prices of the productive factors could be related with the establishment of higher specifications in the process of their improvement, supporting the preference of Greek foreign investors to use Greek physical capital to their ventures. The above findings underline the importance of taking into consideration more explanatory variables than only the traditional macroeconomic determinants in examining FDI flows. It was also shown that in some cases variables that are expected to affect short-term capital flows and portfolio investment, may also arise as important explanatory factors affecting the composition of long-run FDI.

\section{REFERENCES}

Apergis, N., K.P. Katrakilidis and N.M. Tabakis, 2000. Current account deficit sustainability: The case of Greece. Applied Econ. Lett., 7: 599-603. DOI: $10.1080 / 13504850050059087$
Baek, I.M. and T. Okawa, 2001. Foreign exchange rates and Japanese foreign direct investment in Asia. J. Econ. Bus, 53: 69-84. DOI: 10.1016/S01486195(00)00038-2

Barrell, R. and N. Pain, 1998. Real exchange rates, agglomerations and irreversibilities: Macroeconomic policy and FDI in EMU. Oxford Rev. Econ. Policy, 14: 152-167.

Benassy-Ouere, A., L. Fontagne and A. Lahreche-Revil 2001. Foreign Direct Investment and Company Taxation in Europe. 1st Edn., Brussels, ISBN-10: 9290793465, pp: 39.

Blonigen, B.A., 1997. Firm-specific assets and the link between exchange rates and foreign direct investment. Am. Econ. Rev., 87: 447-465.

Brzozowski, M., 2006. Exchange rate variability and foreign direct investment: Consequences of emu enlargement. Eastern Eur. Econ., 44: 5-24.

Campa, J.M. and L. Goldberg, 1995. Investment in manufacturing, exchange rates and external exposure. J. Int. Econ., 38: 297-320. DOI 10.1016/0022-1996(94)01348-V

Campa, J.M., 1993. Entry by foreign firms in the united states under exchange rate uncertainty. Rev. Econ. Stat., 75: 614-622.

Carr, D.L., J. R. Markusen and K.E. Maskus, 2001. Estimating the knowledge-capital model of the multinational enterprise. Am. Econ. Rev., 91: 693-708.

Cushman, D.O., 1985. Real exchange rate risk, expectations and the level of direct investment. Rev. Econ. Stati., 67: 297-308.

Cushman, D.O., 1988. Exchange-rate uncertainty and foreign direct investment in the United States. Weltwirtschaftliches Arch, 124: 322-336. DOI: 10.1007/BF02706782

De Menil, G., 1997. Budgetary Policies in Europe on the Eve of Monetary Union. 1st Edn., Delta, Paris, pp: 18.

Froot, K.A and J.C. Stein, 1991. Exchange rates and foreign direct investment: An imperfect capital markets approach. Q. J. Econ., 106: 1191-1217.

Goldberg, L.S. and C.D. Kolstad, 1995. Foreign direct investment, exchange rate variability and demand uncertainty. Int. Econ. Rev., 36: 855-873.

Goldberg, L.S. and M.W. Klein, 1997. Foreign direct investment, trade and real exchange rate linkages in developing countries. Cambridge University Press.

Goldberg, L.S., 1993. Exchange rates and investment in United States industry. Rev. Econ. Stat., 75: 575-588. 
Hymer, S., 1976. The International Operations of National Firms: A Study of Direct Foreign Investment. 2nd Edn., MIT Press, Cambridge, ISBN-10: 0262080850, pp: 253.

Ito, T., P. Isard, S. Symansky and T. Bayoumi, 1996. Exchange Rate Movements and their Impact on Trade and Investment in the APEC Region. 1st Edn., International Monetary, Washington, ISBN-10: 1557756007, pp: 60.

Kiyota, K. and S. Urata, 2004. Exchange rate, exchange rate volatility and foreign direct investment. World Econ., 27: 1501-1536. DOI: 10.1111/j.14679701.2004.00664.x

Klein, M.W. and E. Rosengren, 1994. The real exchange rate and foreign direct investment in the United States: Relative wealth vs. relative wage effects. J. Int. Econ., 36: 373-389. DOI: 10.1016/00221996(94)90009-4

Lipsey, R.E., 1999. The role of foreign direct investment in international capital flows. University of Chicago Press.

Markusen, J.R. and K.E.Maskus, 1999. Discriminating among alternative theories of the multinational enterprise. Rev. Int. Econ., 10: 694-707. DOI: 10.1111/1467-9396.00359
Markusen, J.R., 2002. Multinational Firms and the Theory of International Trade. 1st Edn., MIT Press, Cambridge, ISBN-10: 0262134160, pp: 440.

Pain, N. and D.V. Welsum, 2003. Untying the gordian knot: The multiple links between exchange rates and foreign direct investment. J. Common. Market Stud., 41: 823-846. DOI: 10.1111/j.1468-5965.2003.00465.X

Sazanami, Y., S. Yoshimura and K. Kiyota, 2003. Japanese foreign direct investment to East Asia and exchange rate policies: Some longer term policy implications after the crisis. Keio Economic Studies, 40: 1-26.

UN, 2008. World Investment Report 2007 Transnational Corporations, Extractive Industries and Development. Academic Foundation, New Delhi, ISBN-10: 8171886744, pp: 322.

Urata, S. and H. Kawai, 2000. The determinants of the location of foreign direct investment by Japanese small and medium-sized enterprises. Small Bus. Econ., 15: 79-103. DOI: 10.1023/A:1008173912813 